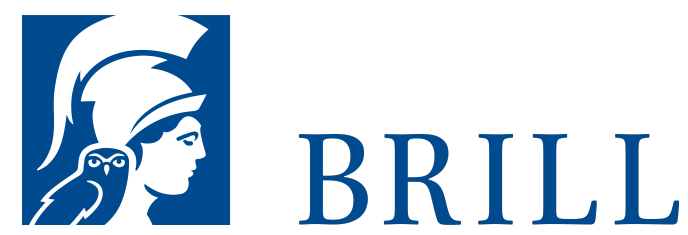

\title{
Was ist literarischer Sarkasmus?
}

Ein Beitrag zur deutsch-jüdischen Moderne

Author: Burkhard Meyer-Sickendiek

Das Buch stellt die erste Studie zum Begriff des Sarkasmus dar. Es geht davon aus, dass ein genuin literarischer Sarkasmus in der deutschsprachigen Literatur erst mit der Einwanderung ostjüdischer Autoren im neunzehnten Jahrhundert entstand. Zwar kannte die Epoche der Aufklärung den Witz und die Romantik die Ironie. Aber erst mit Autoren wie Ludwig Börne oder Heinrich Heine, Daniel Spitzer oder Alfred Kerr, Maximilian Harden oder Karl Kraus, Walter Mehring oder Kurt Tucholsky, Carl Einstein oder Alfred Döblin, Elias Canetti oder Albert Drach entwickelt sich ein literarischer Sarkasmus.

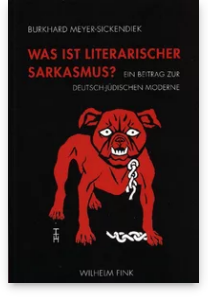

Pages: 616

Seiten

Language:

German

Subjects:

German,

Literature and

Cultural Studies

Publisher: Brill |

Fink

E-Book (PDF)

Released online:

13 Jan 2020

ISBN: $978-3^{-}$

8467-4411-6

List price

USD \$131.00

Paperback

Publication date:

17 Jun 2009

ISBN: 978-3-

7705-4411-0

List price

USD \$131.00 
For more information see brill.com

Order information: Order online at brill.com +44330 333 0049 | customerservices@brill.com Submission information: brill.com/authors

Titles published by Brill | Fink, Brill | mentis or Brill | Schöningh: +49(o)715413279216| brill@brocom.de 